\title{
Narativ i moralni diskurs o braku u Knjizi o Tobiji
}

\section{Boris Beck ${ }^{1}$}

Fakultet političkih znanosti Zagreb

boris.beck@fpzg.hr

UDK 27-245;2-555

Izvorni znanstveni članak

https://doi.org/10.32862/k1.12.2.2

\section{Sažetak ${ }^{2}$}

Knjiga o Tobiji napisana je oko 3. st. pr. Kr. Kanonskom je smatraju katolici i pravoslavni, a protestanti i Židovi ne. Pripovijest nije historijska, nego fiktivna, vrlo dinamične fabule, pri čemu sadrži brojne pouke u starozavjetnom duhu, napose deuteronomističke teologije. Brak joj je središnja tema, a ideal braka predstavlja tjelesna čistoća, borba protiv požude, vjernost, monogamnost i trajnost ženidbenog saveza. Na više mjesta prikazuje se kako su ljubav, privrženost i obzirnost nužni za uspješan brak. Važan je uvjet $i$ endogamnost ženidbe, kako bi supružnici lakše sačuvali i prakticirali vjeru. $\mathrm{Na}$ koncu se molitva - kao izraz povjerenja u Boga - postavlja kao temelj braka čija svrha nadilazi erotsku i prokreativnu funkciju, a ističe se važnost posvećivanja. Knjiga o Tobiji tako u zabavnom obliku čitatelju nudi moralnu pouku koja se nadovezuje na biblijski moral.

Ključne riječi: Knjiga o Tobiji, brak, Bog, ljubav, privrženost

\section{Uvod - kanonski status Knjige o Tobiji}

U ovom će se radu prikazati na koji se način kroz priču i pouku govori o braku u Knjizi o Tobiji, a uvodno će se ukratko dati nekoliko napomena o kanonskom

1 Doc. dr. sc. Boris Beck, Fakultet političkih znanosti Zagreb, Odsjek za novinarstvo i medijsku produkciju.

2 Članak je nastao na temelju predavanja na tribini "Od mladenačke zaljubljenosti do zrele bračne ljubavi: Biblijski pogledi na brak" održane povodom svjetskog “Tjedna braka” 10. veljače 2018. u Centru biblijskih istraživanja Biblijskog instituta u Zagrebu. 
statusu te knjige i njenu sadržaju. Nasuprot kanonskim knjigama, koje sve Crkve, a također i Židovi, smatraju nepogrešivim i Bogom nadahnutim izvorima vjere, stoje knjige koje su napisane na grčkom nakon razdoblja proroka, ili su pak samo na grčkom sačuvane, što je slučaj s Knjigom o Tobiji. Ona je bila uvrštena u najstariji prijevod Starog zavjeta, grčki prijevod nazvan Septuaginta, koji je nastao između 3. i 1. st. pr. Kr. u Aleksandriji, a isto tako i u latinski prijevod Vulgatu, koji je načinio Jeronim u 4 . st.

Jeronim se na Knjigu o Tobiji referirao u prologu svoga prijevoda Knjige $\mathrm{Mu}-$ drosti, kada uspoređuje tu knjigu i Siraha: „Kao što Crkva čita knjige o Juditi, Tobiji i Makabejcima, ali ih ne prihvaća u kanonska Pisma, tako se i ova dva svitka mogu čitati za izgradnju ljudi, [ali] ne i za utvrdivanje autoriteta crkvenih dogmi“ (Gallagher 2007). Iz tih se riječi može shvatiti da Jeronim Knjigu o Tobiji nije prihvaćao kao kanonsku, ali ju je držao valjanom za prenošenje moralnog nauka. Knjiga je u Zapadnoj Crkvi uvrštena u kanon na Rimskoj sinodi 382., a u Istočnoj Crkvi na saboru u Carigradu 692. godine (usp. Rapljenović).

Katolička je crkva na Tridentskom saboru 1546. utvrdila kanon Starog zavjeta na 45 knjiga, uključujući Tobiju. „Starozavjetne knjige koje su izostale iz Talmuda, pod utjecajem Siksta iz Sienne (1520-69) počeli su nazivati deuterokanonskim, a one koje su se nalazile u Talmudu i u Septuaginti nazivali su protokanonskim knjigama“, međutim „u protestantskim njemačkim, mađarskim i ostalim prijevodima u 16. stoljeću još možemo čitati sve deuterokanonske knjige, ali od 17. stoljeća već uopće ne nalazimo nijedan od tih tekstova" (Lőkös 2002, 38). I njemački prijevod Svetog pisma Martina Luthera sadrži deuterokanonske knjige, ali pod nazivom apokrifi, i to uz sljedeću njegovu bilješku: „Te se knjige ne drže jednakima Svetim pismima, ali su ipak korisne i dobre za čitanje" (Evangelical Lutheran Synod), što je očito ponovljeni Jeronimov stav. ${ }^{3}$ Nasuprot Lutheru, Westminsterska ispovijed 1646. odlučno niječe bilo kakvu nadahnutost apokrifa tvrdeći da „nisu božanski nadahnuti, nisu dio kanona i Pisma te nemaju nikakav autoritet za Crkvu tako da se nikako ne mogu odobriti niti na ikoji način koristiti, osim kao drugi ljudski spisi“ (The Confession of Faith of the Assembly of Divines at Westminster).

Sličan stav Jeronimovu i Lutherovu prema apokrifnim/deuterokanonskim knjigama danas imaju Židovi: iako ih „rabini nisu uvrstili u svete spise“, te knjige „sadrže povijest, mudrost, moral, pjesme i pripovijesti“ "iz kojih se mogu steći znanja „o životu Židova, njihovim svjetonazorima i običajima“ (Da-Don 2004, 501). Novi poticaj za proučavanje Knjige o Tobiji dalo je otkriće njenih ulomaka među spisima iz Kumrana - od kojih su tri na aramejskom, a jedan na hebrejskom -

3 Da bi se izbjegao terminološki nesporazum, valja napomenuti da katolici apokrifima nazivaju one knjige koje „protestanti nazivaju pseudoepigrafi - djela slična karaktera i datuma kao i apokrifne knjige, koje se nikad nisu smatrale kanonskima“"(Biblijski priručnik 1989, 461). 
što pokazuje da je Knjiga o Tobiji bila u starini čitana i čuvana među Židovima, a također ukazuje na to da je vjerojatno i nastala na izraelskom tlu (usp. Dimant 2017). ${ }^{4}$

\section{Priča i pouka}

Knjiga o Tobiji ima „moralni cilj“, tj. „želi na daljnja pokoljenja prenijeti moralnu i religioznu pouku u dramskom, umjetničkom i fiktivnom obliku“ (Župarić 2012, 712). Nije riječ, dakle, o historijskoj priči, nego o književnoj koja „može preći granice našeg neposrednog iskustva“ te stvara „,lastiti svijet koji funkcionira prema vlastitoj logici“ (Peleš 1989, 194). Drugim riječima, Knjiga o Tobiji organizira fiktivnu radnju kako bi unutar njezina ustroja afirmirala određenu etiku, pri čemu sama izmišljenost fabule ne znači automatski i njezinu neetičnost.

Vrlo dinamičan narativ prati sudbinu bračnog para Tobije i Ane iz Naftalijeva plemena. Oni sa svojim sinom Tobijom ${ }^{5}$ žive u Asiriji, u Ninivi, u progonstvu, ali pobožno (Tob 1). Otac nesretnim slučajem oslijepi te obitelj zapadne u siromaštvo (Tob 2), na što se otac moli (Tob 3). $U$ istom poglavlju doznajemo da u Ekbatani živi djevojka Sara s neobičnim problemom: demon Asmodej ubija joj muževe prve bračne noći tako da živi nesretno, kao djevica i udovica istovremeno; ona se moli Bogu istovremeno kad i Tobija Stariji te Bog odluči oboma ispuniti molitve. U 4. i 5. poglavlju, uz obilje moralnih naputaka, Tobija šalje sina u Rages po novac, u pratnji anđela Rafaela koji im se predstavlja kao običan čovjek. U 6. poglavlju Tobija na putu kroz pustinju ulovi čudesnu ribu čiji unutarnji organi imaju egzorcistička i ljekovita svojstva, a Rafael ga nagovori da oženi Saru. Nakon svadbe (Tob 7), molitve u prvoj bračnoj noći (Tob 8) i pira (Tob 9) - što je „središte cijele knjige“ (Zovkić 1993, 114) - Tobija i Sara odlaze u Ninivu (Tob 10) gdje sin izliječi oca (Tob 11). Na koncu anđeo otkriva svoj identitet (Tob 12), a otac se moli (Tob 13) te daje zadnje upute sinu pred smrt (Tob 14).

Pažnju čitatelja privlači ljubavni zaplet u kojem su važni dinamički motivi fantastični - poput djelovanja anđela i demona (napose Tob 2 i 12), ali i primjene ribljih iznutrica u svrhu liječenja i egzorcizma (Tob 8 i Tob 11). Frye tu vrstu

4 Zbog paralela s drugom deuterokanonskom/apokrifnom knjigom, Sirahom, smatra se da je Knjiga o Tobiji napisana nakon Ezrina doba - nakon gradnje Drugog Hrama, ali prije podizanja Herodova Hrama. Primjerice, Tob 4,10 i 12,8-9 identični su kao i Sir 3,30, a Tob 4,17 ima paralelu u Sir 12,4-5, iz čega se može zaključiti da su i Sirah i Knjiga o Tobiji nastali istovremeno, ne prije 3. st. pr. Kr. (usp. Howell Toy 1901-1906).

5 U izvornicima otac i sin zovu se jednako, Tobit u aramejskim, a Tobija u grčkim tekstovima - odatle potječe razlika u nazivima knjige u različitim prijevodima; prevoditelj Zagrebačke Biblije, da bi izbjegao zabunu, oca je nazvao Tobit, a sina Tobija. 
naracije smješta u književni oblik romanse: njezin je ključni sastojak pustolovina, što znači da je „romansa po naravi sekvencan i procesualan oblik“, a njezin je sadržaj „,uspješna potraga“, što se sastoji od „pogibeljnog putovanja“, „odsudne borbe“ $i$,uzvišenja junaka“ $(2000,212-213)$ - u čemu je „,cilj putovanja bio ne samo da mladić donese obiteljski novac, nego i da sazre za odgovornost odrasla muškarca" (Zovkić 1993, 114). Međutim, u spominjanju demona Asmodeja Dimant (2017) vidi važan znak za uklapanje Knjige o Tobiji u aramejsku književnost. Druge su poveznice, prema toj autorici, obveza pokapanja mrtvih (Tob 1,17-19; $2,3-8 ; 12,12)$ i razne halahe povezane s davanjem desetine kumranskih stanovnika (1,6-8). Dimant, kao jednu od tipičnih tema izraelske književnosti toga doba, vidi i endogamiju jer je otac oženio ženu iz svoje obitelji $(1,10)$ pa i sinu savjetuje da tako postupi $(4,12-13)$. Budući da je središnja tema Tobije sklapanje braka, uočljive su brojne halahe s tim u vezi: „Nalazimo više talmudskih propisa o kidušin (zarukama), ketubi i vjenčanju. Te halahe proizlaze iz opisa vjenčanja Tobije i Sare bat Reuel“ (Da-Don, 2004, 502). Na taj se način tema upoznavanja mladih i njihova braka razvija kao spoj uzbudljive priče i različitih savjeta u vezi s tim pokazujući na primjeru „povijesnog romana“ kako milosrdni vjernici zadobivaju pomoć „Boga koji spašava“ (Deslaers prema: Zovkić 113).

\section{Brak u Tobiji}

\section{Čistoća i monogamnost}

Istraživači su u Knjizi o Tobiji prepoznali starozavjetnu teologiju, napose deuteronomističku, koja se prepoznaje, primjerice, $\mathrm{u}$ „blagovanju hrane (Tob 1,11), u obvezi pokapanja mrtvih (Tob 1,12-20; 2,38), u solidarnosti s potrebnima (Tob 4,7-11.16)“ (Župarić 2012, 716). Nadalje, očeva „vjernost prema zakonu Božjem osobito se ogledala u pokorničkoj praksi, plemenitosti prema služiteljima svetišta, ljubavi prema Hramu (Tob 1,4s; 13,10s; 14,4s), i monogamnoj ženidbi“ (ibid. 714). Budući da su vjenčanje i brak u središtu zanimanja Knjige o Tobiji - kako u pogledu naracije, tako i u pogledu etike - ispitat će se u daljem tekstu kakav se ideal braka nudi.

Jedna od osobina braka, prepoznata u znanstvenoj literaturi, jest monogamnost. Dok se poligamija u Bibliji spominje u doba patrijarha, ,kasniji biblijski spisi, naročito mudrosne knjige, više o njoj i ne govore“, pretpostavljajući monogamni brak, a „taj novi pogled na brak svoj najbolji izraz nalazi kod Tobije“ (Barišić 1982, 202). Budući da se u Knjizi o Tobiji monogamna ženidba nigdje ne spominje eksplicitno, autor do tog zaključka dolazi implicitno: Tobija Stariji i Ana jedini su supružnici i nema nikakvih naznaka da bi Tobija igdje i ikada imao kakvu drugu ženu ili priležnicu. 
Nadalje, što se mladih supružnika tiče, Knjiga o Tobiji ističe važnost tjelesne čistoće. Tako Sara može mirne duše u molitvi reći sljedeće: „Gospodine, znaš da sam čista od svake nečistoće s muškarcem. U zemlji u koju smo prognani nisam okaljala ni svoje, ni očevo ime“ (Tob 3,14). ${ }^{6}$ Tjelesna čistoća tako nije samo stvar pojedinca, nego i obitelji, odnosno, Sara je za čuvanje obvezana odnosom prema ocu. Slično vrijedi i za mladog Tobiju kojeg otac također upućuje da se „čuva svake požude“ (Tob 4,12). Požuda se ne pojašnjava pobliže, ali poznato je da su u Starom zavjetu česte i tipične zabrane bluda i preljuba (Izl 20,14; Izr 6,24-32) jer Biblija smatra da „spolno zadovoljenje nalazi svoj legitimni izraz jedino u okviru braka“ (Rock 2003, 127). To je zato što Bog „u najvišem stupnju obdržava ćudoređe koje njegova volja traži od stvorenja “ pa „spolna raspuštenost profanira svetost Boga“ (McKenzie 1980, 197). Drugim riječima, tjelesna čistoća ne obvezuje Saru i Tobiju samo u odnosu prema njihovom roditeljima, nego prema Bogu jer između stvorenja i Stvoritelja postoji odnos uzajamnosti: Bog postavlja standarde ponašanja koje i sam ispunjava, a ljudi održavaju takvo ponašanje iz ljubavi. Zahtjevi koji se postavljaju pred Saru i Tobiju nužni su za kvalitetu njihova odnosa prema Bogu jer je taj odnos utemeljen na moralu.

Možemo zaključiti da Knjiga o Tobiji prihvaća židovske propise kako ih čuva Ponovljeni zakon, da se u sklopu toga mladim osobama i muškog i ženskog roda brane spolni odnosi izvan braka, pa dakle i vjenčanima izvan njega, te da je brak monogaman.

\section{Molitva, čovjek i brak}

Na početku braka Sare i Tobije - uz uvjete da zaručnici pripadaju istoj obitelji (pa posljedično i istom narodu i vjeri) te da budu čisti u seksualnom smislu - stoji još jedan važan uvjet: molitva. Na potrebu molitve Rafael unaprijed upozorava mladog Tobiju: „Kad joj poželiš prići kao muž, oboje ustanite i pomolite se. Molite da vam Gospodar neba udijeli milosrđe i spas“ (Tob 6,18). Molitve u Knjizi o Tobiji ,izgovaraju i muške i ženske osobe“ i „na ključnim spojevima Knjige“ te ,imaju veliku težinu i vrijednost“ (Župarić 2012, 726). ${ }^{7}$ Nije zato neobično da upravo u ključnom trenutku zapleta - pred bračno sjedinjenje Tobije i Sare, sjedinjenje koje je dotad prekidao demon ubijajući supruga - mladenci pristupaju molitvi, kako je opisano u Tob 8,1-9: pošto su obredi i svečanosti završili, ukućani su izašli i zatvorili za mladencima vrata sobe; Tobija se digao s ležaja i rekao Sari: „Sestro, ustani da se pomolimo. Molimo svojega Gospodina da nam se smiluje i

6 Svi navodi iz Knjige o Tobiji preuzeti su iz prijevoda Mate Zovkića objavljena 2007. u časopisu Gordogan, kako je navedeno u bibliografiji; ostali navodi iz Svetog pisma preuzeti su iz Zagrebačke Biblije.

7 Primjeri molitvi u Knjizi o Tobiji: 3,2-6,11-15; 8,5-8,15-17; 11,13-15. 
sačuva nas zdrave." Ona je na to ustala i zajedno su molili za zdravlje:

„Ti si odredio: 'Nije dobro da muškarac bude sam, načinimo mu pomoć sličnu njemu! Ovu svoju sestru ne uzimam iz pohote, nego radi istine. Udostoji nam se iskazati milosrđe da zajedno doživimo starost.' Zatim su zajedno rekli 'Amen, amen!' i otišli na spavanje."

Spolnost, zajedno s njezinom prokreativnom ulogom, na ovome mjestu zamjenjuje molitva kako bi došlo do „milosnog zahvata“ (Zovkić 1993, 114), čime se ukazuje na prvenstvo nadnaravnog reda nad onim prirodnim.

Tobijin apel u molitvi da sa Sarom „zajedno doživi starost“ pokazuje „ozbiljnost bračnog programa koji su si zacrtali“ te da „započinju zajednički život ne samo kao rezultat sadašnje sklonosti i potrebe za blizinom druge osobe, nego gledaju na cjelinu i dovršetak ljudskog života" (Bilić). Zahtjevima za monogamijom te predbračnom i bračnom čistoćom na taj se način pridružuje i zahtjev za trajnošću braka - što je u zadnjem poglavlju Knjige o Tobiji i eksplicirano: supružnici su zajedno sa svojom djecom doživjeli duboku starost. Kao i uvjet monogamije, tako se i uvjet trajnosti braka odražava pažljivim prikazom ostarjeloga bračnog para Tobije i Ane. Jamačno je s monogamijom spomenutom u prethodnom odjeljku u svezi činjenica da u molitvi tijekom prve bračne noći mladenci navode Knjigu Postanka ${ }^{8}$, čime se podsjeća na to da je „brak, zajedno sa subotom, uspostavljen u Edenu" (Rock 2003, 125) te da se vjenčanjem vrši Božja volja, odnosno brak je za Tobiju i Saru „ostvarenje onoga što [im] je Bog na temelju svoje božanske prosudbe podario“ (Bilić). Važnost molitve - kako u cijeloj Knjizi o Tobiji, tako i u samom činu vjenčanja, oko kojega se cijela knjiga vrti - pokazuje da je za čovjeka sržan odnos prema Bogu te da se svi međuljudski odnosi, pa tako i bračni, smiju i moraju promatrati samo unutar odnosa prema Stvoritelju. To što bi odnos čovjeka i Boga trebao biti ne samo čist i ekskluzivan, nego i trajan, postavlja se kao uvjet i za brak.

\section{Veselje i blagoslov}

Ceremonijalnost sklapanja braka i danas je širom svijeta veoma važna, a važna je bila i u biblijsko doba, odnosno postbiblijsko, ako slijedimo shvaćanje da je knjiga o Tobiji napisana pošto je kanon već bio zaključen. Prema Rock (126) biblijskom obredu vjenčanja prethodili su biranje mladenke i ugovaranje braka, što je popraćeno darivanjem (usp. Izakov dar Rebeki u Post 24) te zaruke (Pnz 22,23-27). Sklapanje braka obvezno je bilo popraćeno gozbom na kojoj uz obitelj sudjeluju i prijatelji (Suci 14,11, Post 29,27), dok bi „spolni odnos označio vrhunac sklapanja braka i kraj svadbene svečanosti“ (Rock 2003, 126) s tim da bi se po 
potrebi nevinost mladenke dokazala krvavom plahtom (Pnz 22,13-21).

U Knjizi o Tobiji mladenku nije izabrala mladoženjina obitelj, nego pratilac, anđeo Rafael - no mladenka je izabrana posve u skladu s očevim napucima, a i Rafael je mladićev skrbnik kojeg je ovlastio otac. Također, nisu dani darovi niti su protekle zaruke - što je razumljivo iz konteksta priče, tj. da su mladenku svi izbjegavali i da se mladenkinoj obitelji žurilo da se Tobija ne bi predomislio. Gozba se ipak održala - na sam dan vjenčanja svatovi su večerali (Tob 8,9), a kad se pokazalo da je mladoženja preživio, slavlje je produženo na dva tjedna $(11,9)$; potom se svatovima pridružio poslovni suradnik Tobije Starijeg, Gabael iz Ragesa (Tob 9,6), na taj način simbolično nadomjestivši odsutnog oca.

Samo vjenčanje i doček mladenke opisani su vrlo lijepo. Saru je njezin otac Raguel pozvao, uzeo za ruku i predao Tobiji uz sljedeće riječi: „Dajem ti je za ženu po zakonu i odredbi Mojsijeve knjige“, „Uzmi je i sretno odvedi svom ocu“ te „Neka vam nebeski Bog udijeli mir“ (Tob 7,12-13) - moguće je da su te riječi odražavale stvarni obred vjenčanja. Doček mladenaca u Ninivi bio je također srdačan, ovo su riječi starog Tobije:

„Dobro došla, kćeri i želim ti svaku sreću! Neka je blagoslovljen Bog koji te je, kćeri, doveo k nama! Neka je blagoslovljen tvoj otac, neka je blagoslovljen moj sin Tobija, a budi blagoslovljena i ti, kćeri! Uđi sretno u svoju kuću, s blagoslovom i radošću!“ (Tob 11,17).

Iz tih riječi izbija toplina, i svakako su uzor i danas - jer mladenci izlaze iz svojih obitelji, a još nisu osnovali vlastitu te im u tom trenutku svakako treba razumijevanje. „Perspektiva koju ova biblijska knjiga nudi za brak i obitelj je blagoslov i velika mjera radosti“ (Bilić) - tako da na već dosad uočene osobine braka, možemo dodati još dvije, jednako važne: ujedinjavanje i radost, kako mladenaca, tako i obitelji.

\section{Ljubav i privrženost}

Od mladog Tobije očekuje se da postane otac i tako nastavi lozu:

„Uvijek se sjećaj naših očeva Noe, Abrahama, Izaka i Jakova. Svi su se oženili ženama iz svojega roda i bili sretni sa svojom djecom, a njihovo će potomstvo naslijediti zemlju“" (Tob 4,12).

Tim je riječima otac poticao sina. ${ }^{9} \mathrm{Na}$ taj način obnavlja se Božji narod, o čemu svjedoči i jedna druga uputa starog Tobije: „Zapovjedite djeci da čine ono što je pravedno i iskazuju samilost, da se spominju Boga i da uvijek blagoslivljaju njegovo ime, iskreno i svom snagom“" (Tob 14,9).

9 U tim riječima čuje se odjek drevne zapovijedi „Plodite se i množite“ (Post 1,28), i dubokog osjećaja da djeca predstavljaju „Jahvin dar“ (Ps 127,3). 
Dakako, djece ne bi bilo bez majke, i zato njoj ide svako moguće poštovanje: „Poštuj majku i ne čini joj ništa nažao cijelog njezina života. Iskazuj joj dobro i nemoj joj nikakvim svojim postupkom ožalostiti dušu. Sinko, ne zaboravi je jer je podnijela mnoge nevolje dok je bila trudna s tobom" (Tob 4,3-4). Onako kako je bio naučen u mladosti odnositi se prema majci, mladi Tobija sada će se odnositi prema svojoj supruzi kada i ona postane majka.

Uopće je pažljivost i obzirnost bitna za pisca Knjige o Tobiji, pa se tako od supružnika očekuje nježnost i uvažavanje. „Brak nije više samo sredstvo rađanja (...); sve više do izražaja dolazi osobni odnos bračnih drugova, odnos ljubavi“ (Barišić 1982, 202). Knjiga o Tobiji stavlja velike društvene zahtjeve pred bračne partnere, ali ukazuje i na važnost uzajamne bliskosti, a izričito navodi i najvažniji sastojak braka, a to je duboka i iskrena ljubav:

„Čim je Tobija od Rafaela doznao da postoji djevojka iz očeva roda, odmah ju je snažno zavolio i srcem joj se priklonio“ (Tob 6,18). „To je trenutak kad u njegovu srcu započinje iskrena ljubav prema Sari“, no „fenomen odlučujuće simpatije i zaljubljenosti (...) ne staje na hirovitoj privlačnosti izgleda i vanjštine, nego se krije duboko unutar osobe" (Bilić).

Tjelesna ljubav stalno mora imati pandan u duhovnoj. Pa dok su Sara i mladi Tobija na početku životnog puta, i u prvom dijelu knjige ne znamo što će biti s njima, u Knjizi o Tobiji imamo i drugi bračni par u koji se možemo ugledati: oca Tobiju i Anu. Njihov odnos nije bez trzavica, ali ispunjen je poštovanjem. Budući da je stari Tobija oslijepio, nije više mogao biti hranitelj obitelji, što mu je teško palo: „Za to je vrijeme moja žena Ana zarađivala radeći ženske poslove. Završene radove slala je naručiteljima koji su joj plaćali“, (Tob 2,11) kaže Tobija o svojoj marljivoj supruzi. Ana se tako pokazuje kao vrsna žena opisana u 31. poglavlju Mudrih izreka, koja ustaje prije ukućana i skrbi se za sve njihove potrebe.

Međutim, kada je Ana smatrala da njezin muž griješi, i da nije uputno sina slati na opasno putovanje, nije oklijevala suprotstaviti mu se. U Knjizi o Tobiji stoji da je mladićeva majka plakala i govorila suprugu:

„Zašto si uopće slao mog sina? Nije li on kao štap našim rukama, na koji se oslanjamo kad ulazimo i izlazimo? Ne treba gomilati novac na novac, nego ga smatrati bezvrijednim u usporedbi s našim sinom. Neka nam bude dovoljno ono što nam Bog daje za život" (Tob 5,18-19).

Suprug na njezine riječi ne odgovara razdražljivo, nego je smiruje, i to ovim riječima (12,21-23): „Ne uznemiruj se! Naš će sin sretno otputovati i tvoje će ga oči ugledati onog dana kad ti se sretno vrati. Ne uznemiruj se i nemoj strahovati, sestro moja. Prati ga dobri anđeo, zato će mu putovanje biti uspješno." I u Knjizi o Tobiji stoji dalje: „Majka je tada prestala plakati“, što je jamačno jedan od najdirljivijih prizora u cijeloj Knjizi o Tobiji. 
„Tako dobivamo zanimljiv nacrt koji je suvremenom uhu možda malo stran: ponajprije dolazi ljubav, zatim duhovnost i molitva, tek potom tjelesna blizina i nježnost. Sva tri koraka u ovom trolistu su važna; tri stepenice do zajedništva“"(Bilić).

Kako to zajedništvo izgleda, vidi se na starijem bračnom paru.

\section{Duhovno i materijalno blagostanje}

Uz brojne i iscrpne duhovne pouke, Knjiga o Tobiji ne zanemaruje materijalnu stranu čovjekova života jer „na instituciju braka utjecali su i socijalno-ekonomski uvjeti“ (Barišić 1982, 202). Knjiga o Tobiji podsjeća mladence da valja živjeti skromno i pošteno pa se među brojnim savjetima nalazi i ovaj: „Oholost vodi u propast i veliku smutnju, a razuzdanost na stranputicu i u veliku oskudicu. Raskalašenost je majka gladi“ (Tob 4,13). Na taj se način pobožnost vidi kao uvjet i duhovnog i materijalnog blagostanja: „Gospodina se, sinko, spominji dok si živ. Ne odaj se grijehu i ne prestupaj njegove zapovijedi. Cijeli život budi pravedan i ne idi putovima nepravednosti jer će oni koji čine istinu uspijevati u svojim djelima" (Tob 4,19). Indikativno je da se ljubav i pripadnost rodu spominju zajedno i da se od Tobije očekuje da „ženu najprije odabere iz svojega naroda“ (Tob 4,12 ). Jamačno, to je zato što će tako najbolje zadržati svoju pobožnost i uspjeti obdržavati Božje zapovijedi. Oholost je prekršaj „moralnog reda s obzirom na osobni i društveni život“, a u konkretnom slučaju značila bi „odbiti očeve upute glede odabira životne suputnice“, odatle u Knjizi o Tobiji vrlo strogo inzistiranje na endogamiji koje „cilja na vjersku čistoću“ (Župarić 2012, 725). Tim se riječima zaokružuje pouka o braku, kao o nečemu što je teško uspostaviti i još teže sačuvati, ali je vrijedno svakog truda - a vjerne Bogu „pratit će dobri anđeo“, kako jamči ova šarmantna i poučna knjiga što privlači i nadahnjuje čitatelje više od dva milenija.

\section{Zaključak}

Knjiga o Tobiji napisana je vjerojatno sredinom 3. st. pr. Kr, a kumranska otkrića pokazuju da je u antici bila među Židovima čitana i štovana, pri čemu je vjerojatno da je i nastala na području Palestine. Kanonskom je smatraju katolici i pravoslavni, dok je vjernici protestantske baštine ubrajaju u apokrife, a Židovi u tzv. odložene knjige koje se ne smatra nadahnutim, ali vrijedne su jer daju uvid u život i razmišljanje vjernika u prošlosti; konkretno, u Knjizi o Tobiji „rečeno je da je Tobija uzeo Saru po vjeri Mojsijevoj, da su molili blagoslove i napisali ketubu, kao što je propisano u Talmudu, a održalo se do danas“ (Da-Don 2004, 502).

U Knjizi o Tobiji Bog ljudima u nevolji, koji ga pobožno zazivaju, šalje anđela Rafaela da sve uredi - provest će mladog Tobiju kroz opasnu pustinju i pomoći 
mu da nadmudri demona te oženi Saru, ne zaboravivši pritom na novčanu stranu pothvata, a također i na sljepoću njegova oca. Riječ je, dakle, o Božjem zahvatu, a vjerska pouka daje se pod krinkom dramatične pripovijesti: „Autor dok priča zanimljivu prispodobu o Tobiji ujedno religiozno odgaja. Vrijednosti i praksa Židova se prenosi na slušatelja u formi avanturske priče“ (Rapljenović). Knjiga o Tobiji obiluje poukama koje se uklapaju u starozavjetnu teologiju, napose u njen deuteronomistički vid, te je lako uočljivo zašto su je, primjerice, Jeronim ili Luther smatrali korisnom za čitanje.

Središnja tema Knjige je brak dvoje mladih, ali pozornost je svrnuta manje na romantični i tjelesni dio, a više na njegovu duhovnu bit jer „brak ima religiozni karakter i otkupiteljsku snagu“" (Barišić 1982, 202). Brak, kako se shvaća u Knjizi o Tobiji, takav je savez između dvoje ljudi koji mora biti ekskluzivan i trajan, kako bi se unaprijedila pobožnost supružnika: ženidba je u Knjizi o Tobiji „snažno iskustvo što ga ostvaruju dvije osobe i ona je sveta stvar. Treba biti monogamna (Tob 8,6), iz plemena otaca, pripravljena neokaljanim životom (Tob 3,14; 4,12), sklopljena po volji Božjoj (Tob 8,7) i s blagoslovom roditelja (Tob 7,12; 8,17; 10,13)" (Župarić 2012, 725). Iz tog aspekta treba razumijevati endogamni karakter vjenčanja - jer se samo tako može očuvati privrženost židovskoj vjeri.

Nadalje, ključni su sastojci braka radost, uzajamna potpora, obzirnost, ljubav i kontemplacija: „Bračni susret mladenaca Tobije i Sare prožet je razmišljanjem i molitvom. (...) a partneri jedno drugom posreduju ozdraviteljsko ozračje“ (Deselaers prema Zovkić 1993, 114). Ovdje se konačno vidi kako su i izlječenje očeva sljepila i spašavanje Sare od demona samo prispodobe pobjede vjere nad nevjerom i pravednosti nad grijehom te da je svrha braka upravo očuvanje kreposti vjere, ufanja i ljubavi. Na primjeru Tobije i Sare pisac Knjige o Tobiji pokazuje kako njihov brak nije usmjeren samo na njih dvoje i njihovu djecu - iako se vodi računa i o sreći supružnika i o blagodati njihova potomstva - nego da je sržno poslanje braka čuvanje i ostvarivanje pobožnosti.

\section{Bibliografija}

Barišić, Marin. 1982. „Biblijsko poimanje braka“. Crkva u svijetu, Vol. 17, No. 3. 198-209.

Biblija. Stari i Novi Zavjet. Zagreb, Kršćanska sadašnjost.

Biblijski priručnik. Mala enciklopedija. 1989. Ur. David i Pat Alexander. Zagreb, Duhovna stvarnost.

Bilić, Niko. „Tobija i Sara“' http://amdg.ffdi.hr/tobija.htm

Da-Don, Kotel. 2004. Židovstvo: život, teologija, filozofija. Zagreb, Profil.

Dimant, Devorah. 2017. „Aramaic Tobit at Qumran“. http://www.ancientjewre- 
view.com/articles/2017/3/22/aramaic-tobit-at-qumran (pristupljeno: 27.04.2017.)

Evangelical Lutheran Synod, http://els.org/resources/answers/apocrypha/ (pristupljeno: 27.04.2017.)

Frye, Northrop. 2000. Anatomija kritike. Zagreb, Golden marketing.

Gallagher, Ed. 2017. „Jerome's Prologue to the Books of Solomon“. http://sanctushieronymus.blogspot.hr/2007/12/jeromes-prologue-to-books-of-solomon.html (pristupljeno: 27.04.2017.)

Howell Toy, Crawford. 1901-1906. „Tobit, Book of“. The Jewish Encyclopedia. New York, Funk and Wagnalls. http://www.jewishencyclopedia.com/ articles/14422-tobit-book-of (pristupljeno: 27.04.2017.)

Lőkös, István. 2002. „Fabulae i apocrypha: estetska determinacija u starozavjetnoj Knjizi o Juditi“. Colloquia Maruliana, XI, 37-44.

Knjiga o Tobiji. 2007. prev. Mato Zovkić. Gordogan, 11-14, 71-77.

McKenzie, John L. „Starozavjetna biblijska teologija“ u: Biblijska teologija Staroga i Novoga zavjeta. Zagreb, Kršćanska sadašnjost, 141-179.

Peleš, Gajo. 1989. Priča i značenje. Zagreb, Naprijed.

Rapljenović, Robert. „Knjiga o Tobiji“. http://amdg.ffdi.hr/tobija_rapljenovic. pdf (pristupljeno: 27.04.2017.)

Rock, Calvin B. 2003. „Brak i obitelj“. Biblijski pogledi, Vol. 11, No. 1-2, 123-152.

The Confession of Faith of the Assembly of Divines at Westminster. file:///C:/ Users/boris.beck/Desktop/The\%20Confession\%20of\%20Faith.html (pristupljeno: 27.04.2017.)

Zovkić, Tobija. 1993. „Duhovni komentar Knjige o Tobiji. (prikaz knjige P. Deselaers; Das Buch Tobit, Geistliche Schriftlesung 11, Patmos Verlag Dusseldorf 1990, 247 str). Crkva u svijetu, Vol. 28, No.1, str. 113-115.

Župarić, Drago. 2012. „Moralni naglasci u Knjizi o Tobiji“. Bogoslovska smotra br. 82, 3, 711-729. 
Boris Beck

\title{
The Narrative and Moral Discourse Regarding Marriage in Tobit
}

\begin{abstract}
Tobit was written around the third century B.C. It is considered canonical by the Catholics and the Orthodox believers, but not by Protestants and the Jews. The story is not historical but fictional, with a very dynamic narrative, containing numerous lessons in the spirit of the OT, particularly those relating to Deuteronomy theology. The central theme of the book is marriage and the ideal marriage is portrayed in terms of physical purity, struggling against lust, faithfulness, monogamy, and the permanence of the marriage covenant. It is pointed out in many places that love, fondness, and consideration are necessary for a successful marriage. Another important condition is the endogamy of marriage, so that the spouses would be able to keep and practice their faith more easily. And finally, prayer as the expression of trust in God is posited as the foundation of a marriage which purpose transcends the erotic and procreative functions and emphasis is also placed on the importance of consecration. So in a fun way, Tobit offers a moral lesson which ties in with Biblical morality.
\end{abstract}

